\title{
Clinical and prognostic significances of nuclear and cytoplasmic KIT expressions in extrahepatic bile duct carcinomas
}

\author{
Seung-Mo Hong ${ }^{1}$, Ilseon Hwang ${ }^{2}$, Dong Eun Song ${ }^{2}$, Jene Choi ${ }^{2}$ and Eunsil $\mathrm{Yu}^{2}$ \\ ${ }^{1}$ Department of Pathology, Johns Hopkins Medical Institutions, Baltimore, MD, USA and ${ }^{2}$ Department of \\ Pathology, University of Ulsan College of Medicine, Asan Medical Center, Seoul, Korea
}

\begin{abstract}
After receiving FDA approval as a therapeutic regimen in gastrointestinal stromal tumors, the tyrosine kinase inhibitor imatinib mesylate has been applied to the treatment of other solid malignant neoplasms. To evaluate the usefulness of imatinib mesylate as a possible therapeutic regimen in extrahepatic bile duct carcinomas, an immunohistochemical study for KIT was performed in 289 cases of extrahepatic bile duct carcinomas, and mutational analysis of exon 11 of the c-kit gene was performed in 20 cases that were arbitrarily retrieved from the cases with KIT expression. Cytoplasmic KIT expression was observed in 54 cases (19\%) and nuclear KIT in 58 cases $(20 \%)$ of extrahepatic bile duct carcinoma. Nuclear KIT expression was more frequent in cases with vascular invasion $(P<0.001)$, whereas cytoplasmic KIT expression was more common in tumors of T1-T3 than in those of T4 $(P=0.04)$, and was more frequently observed in cases with a papillary growth pattern $(P=0.03)$. Patients with cytoplasmic KIT-positive tumors had significantly better survival both by univariate $(P=0.01)$ and multivariate analyses $(P=0.04)$. Infrequent cytoplasmic KIT expression without mutation of exon 11 suggests that imatinib mesylate may not be effective for the treatment of extrahepatic bile duct carcinoma. However, immunohistochemical study for KIT may be helpful in routine pathologic examinations for evaluating better prognosis for patients with extrahepatic bile duct carcinoma. In addition, more frequent nuclear expression of KIT in cases with vascular invasion suggests that nuclear KIT expression may contribute to the progression of extrahepatic bile duct carcinoma.
\end{abstract}

Modern Pathology (2007) 20, 562-569. doi:10.1038/modpathol.3800771; published online 30 March 2007

Keywords: extrahepatic bile duct; carcinoma; cholangiocarcinoma; KIT expression; mutation; nucleus

Extrahepatic bile duct carcinoma is an uncommon neoplasm with a dismal prognosis. ${ }^{1}$ Surgical resection is currently the most effective therapy only for a limited number of patients. Although chemotherapy and radiation therapy have been administered in an attempt to reduce the recurrence after resection, their effectiveness has not been proven completely.

Despite the fact that several molecular mechanisms of biliary carcinogenesis have been suggested, the pathogenesis of extrahepatic bile duct carcinoma is still poorly understood. The proto-oncogene $c$-kit encodes a transmembrane tyrosine kinase receptor (KIT). ${ }^{2}$ The KIT activation by dimerization of two adjacent receptors occurs through binding of the ligand, stem cell factor (SCF), and results in

Correspondence: Dr E Yu, MD, PhD, Department of Pathology, University of Ulsan College of Medicine, Asan Medical Center, 388-1 Pungnap-dong, Songpa-ku, Seoul 138-736, Korea.

E-mail: esyu@amc.seoul.kr

Received 06 November 2006; revised and accepted 31 January 2007; published online 30 March 2007 phosphorylation of various substrates that mediate intracellular signal transduction. SCF-KIT signaling plays a critical role in the development of erythrocytes, mast cells, melanocytes, and interstitial cells of Cajal..$^{3-5}$ In malignant neoplasms, gain-of-function mutation of $c$-kit gives rise to continuous autoactivation of KIT without SCF in gastrointestinal stromal tumors (GISTs) ${ }^{6}$ which express cytoplasmic KIT. Cytoplasmic KIT expression also has been documented in many other human malignant neoplasms, including dysgerminoma, ${ }^{7}$ seminoma, ${ }^{8}$ malignant melanoma, ${ }^{9}$ neuroblastoma, ${ }^{10}$ breast cancer, ${ }^{11}$ small and nonsmall-cell lung, ${ }^{12}$ endometrial, ${ }^{13}$ ovarian, and thyroid cancers. ${ }^{14}$ Imatinib mesylate (STI571, Gleevec) is a selective inhibitor of tyrosine kinases, including BCR-ABL, KIT, and plateletderived growth factor receptor (PDGFR). It binds to the adenosine triphosphate binding site of target tyrosine kinases and hinders phosphorylation of downstream target proteins. ${ }^{15}$ Effectiveness of treatment with imatinib mesylate has been reported in metastatic and/or unresectable GIST, ${ }^{16}$ expressing 
cytoplasmic KIT. ${ }^{6,17,18}$ Although one previous study demonstrated the possibility of using imatinib mesylate in cholangiocarcinoma as a therapeutic regimen, the information regarding KIT expression and its clinical significance in extrahepatic bile duct carcinoma is still unclear. ${ }^{19}$ In this study, we performed immunohistochemical studies and mutational analysis of $c$-kit on a large number of extrahepatic bile duct carcinoma cases to examine whether imatinib mesylate can be used as a possible therapeutic regimen in patients with extrahepatic bile duct carcinoma.

\section{Materials and methods}

\section{Case Selection}

The surgical pathology database of Asan Medical Center, University of Ulsan College of Medicine, Seoul, Korea was searched from 1991 to 2005, and 289 cases of surgically resected extrahepatic bile duct carcinomas were included in this study. Carcinomas with the epicenter in the extrahepatic bile duct were included, and carcinomas arising in the gallbladder or in the intrahepatic bile duct with extension to the extrahepatic bile duct were not included. Carcinomas with the epicenter in the ampulla of Vater or in the pancreas, and those with obvious precancerous epithelial changes in the ampulla of Vater or in the pancreas were excluded.

For tumor sampling, we followed the standard protocol of our group, which was previously reported elsewhere. ${ }^{20}$ In brief, two longitudinal sections of full thickness of bile ducts and surrounding tissues was obtained from the area spanning the ampulla of Vater to the proximal ends of the extrahepatic bile duct in cases with Whipple's operation specimens. The tumor and surrounding tissues were divided and submitted for histologic examination in 3-4 tissue cassettes from each longitudinal section. The specimens were routinely processed and stained with hematoxylin and eosin.

Medical records were reviewed to obtain information about each patient's age, sex, surgical procedure, survival time, and survival status. Information regarding tumor location, size, and growth pattern were obtained by reviewing pathology reports. Hematoxylin and eosin-stained slides for all cases were evaluated for histopathologic characteristics.

\section{Tissue Microarray Construction}

Tissue microarrays were constructed as described previously. ${ }^{21}$ In brief, one (S-MH) of the authors reviewed all slides containing tumor sections. The number of total slides ranged from 6 to 21 (mean, 12.3; median, 12) and that of slides containing tumor sections ranged from 3 to 11 (mean, 4.4; median, 4). One to four representative slides and matched blocks from each case were selected for tissue microarray construction. The designated area in each recipient block was punched with a tissue cylinder and then transferred to a recipient tissue microarray block. One to four tissue cores were selected from donor blocks for each case. Two hundred and eighty nine cases of extrahepatic bile duct carcinomas and 20 normal biliary epithelia were represented on the blocks.

\section{Immunohistochemical Studies}

Immunohistochemical staining was carried out on tissue microarray sections using the avidin-biotin method and a commercially available kit (Vectastain Elite ABC kit, Vector Laboratories, Burlingame, CA, USA). Deparaffinized sections were treated with methanol containing $3 \% \mathrm{H}_{2} \mathrm{O}_{2}$ for $10 \mathrm{~min}$ after conducting antigen retrieval at $95^{\circ} \mathrm{C}$ for 5 min using a microwave oven. After washing with phosphatebuffered saline, blocking serum was applied for $10 \mathrm{~min}$. The anti-KIT primary antibody (polyclonal rabbit antibody, A4502, Dako, Glostrup, Denmark, 1:400 dilution) was allowed to react at room temperature for $30 \mathrm{~min}$. After washing in phosphate-buffered saline, a biotin-marked secondary antibody was applied for $10 \mathrm{~min}$ followed by a peroxidase-marked streptoavidin for an additional $10 \mathrm{~min}$. The reaction was visualized by $3,3^{\prime}$-diaminobenzidine tetrahydrochloride. The nuclei were counterstained with Harris hematoxylin. Interstitial cells of Cajal that were included in normal intestinal tissues and mast cells around tumors were used as a positive control for KIT. Negative controls were composed of identically treated histologic sections with the omission of primary antibodies. Three independent pathologists (S-MH, DES, and EY) evaluated the slides separately without any clinical information. We counted positive cells among 500 cells in the most active areas and provided actual numbers of positive percentage. The immunoreactivity for each case was interpreted as positive (more than or equal to $5 \%$ ) or negative (less than $5 \%$ ). Most of the cases that were positive for cytoplasmic KIT stained diffusely. Edge effect is one the frequent artifacts that one can encounter during immunohistochemical studies. In order not to interpret false positives as true positives, we did not consider a case as positive when a single or small number of cells that stained for KIT were observed at the edge of each core. For those cases with discrepancy, a decision was made based on the consensus opinion.

DNA extraction was performed as described previously. ${ }^{22}$ Briefly, manually dissected tissues were digested in a lysis buffer $(10 \mathrm{mM}$ Tris, pH 8.0, $10 \mathrm{mM}$ EDTA; $0.5 \%$ SDS, $100 \mathrm{mM} \mathrm{NaCl}$ ) with proteinase $\mathrm{K}(500 \mu \mathrm{g} / \mathrm{ml}$, Boehringer Mannheim, Germany) at $60^{\circ} \mathrm{C}$ for 2 days. The samples were centrifuged at 13000 r.p.m. after boiling for $2 \mathrm{~min}$ to remove debris, followed by extraction with phenol/ chloroform and ethanol precipitation of the super- 
natant. Amplification was performed in a total reaction volume of $20 \mu \mathrm{l}$ with $10 \mathrm{mM}$ Tris-HCl, $50 \mathrm{mM} \mathrm{KCl}, 1.5 \mathrm{mM} \mathrm{MgCl}_{2}, 200 \mu \mathrm{M}$ deoxynucleoside triphosphate, $200 \mathrm{nM}$ each primer and $1 \mathrm{U}$ of AmpliTaq Gold DNA polymerase (Roche Applied Science, Indianapolis, IN, USA). The following primers were employed for c-kit: forward, $5^{\prime}$-ATA TTT ACA GGT AAC CAT TTA TTT G-3'; reverse, 5' GGA AAG CCC CTG TTT CAT AC-3'. The thermal cycling condition was comprised of an initial denaturation step at $95^{\circ} \mathrm{C}$ for $5 \mathrm{~min}$, followed by 35 cycles of $95^{\circ} \mathrm{C}$ for $40 \mathrm{~s}, 55^{\circ} \mathrm{C}$ for $30 \mathrm{~s}$, and $72^{\circ} \mathrm{C}$ for $40 \mathrm{~s}$ and then $72^{\circ} \mathrm{C}$ for $10 \mathrm{~min}$. The PCR products were purified and sequenced with an ABI 377 automated fluorescent DNA sequencer (PE Applied Biosystems, Foster City, CA, USA).

\section{Statistical Analysis}

Statistical analyses were performed using SPSS version 11 (SPSS Inc., Chicago, IL, USA). Associations between categorical variables were examined using the Pearson's $\chi^{2}$ and Fisher's exact tests. Survival rates were calculated by the Kaplan-Meier method and statistical significance was examined by the log-rank test and the Cox proportional hazards regression model. A $P<0.05$ was considered statistically significant.

\section{Results}

\section{Clinicopathologic Characteristics of Cases}

The ages of the patients included in this study ranged from 30 to 84 years (mean, 60.4 years; s.d., 9.6 years). Two hundred and seven patients were men and 82 were women. The tumors showed an infiltrative growth pattern in 236 cases, a papillary growth pattern in 34 , and a nodular growth pattern in 19. Ninety-four tumors were well differentiated, 149 moderately differentiated, and 46 poorly differentiated. The tumor sizes ranged from 0.4 to $6 \mathrm{~cm}$ (mean, $2.5 \mathrm{~cm}$ ). Forty-eight cases were T1 tumors (tumors were located within bile duct), 105 T2 (tumors were located beyond the bile duct), 110 T3 (tumors invaded the pancreas, liver, or unilateral portal vein, or hepatic artery), and 26 T4 (tumors invaded the duodenum, stomach, colon, or main portal vein or common hepatic artery). Invasions into the pancreas, duodenum, and liver were observed in 124 (43\%), $26(9 \%)$, and $12(4 \%)$ cases, respectively. One hundred and ninety-five $(68 \%)$ and $79(27 \%)$ cases showed perineural and vascular invasion, respectively. Evaluation of lymph nodes was available in 273 of 289 cases (95\%). The total number of retrieved lymph nodes ranged from 1 to 45 (mean, 9.5; s.d., 7.8) in 273 cases. Lymph node metastasis occurred in 92 cases (34\%). The number of metastatic lymph nodes ranged from 1 to 19 (mean, 2.8; s.d., 2.8). The histologic types of extrahepatic bile duct carcinomas were as follows: 244 adenocarcinoma, not otherwise specified (85\%), 21 papillary carcinoma $(7 \%)$, nine intestinal-type adenocarcinoma ( $3 \%$ ), six adenosquamous carcinoma $(2 \%)$, five mucinous carcinoma $(2 \%)$, two sarcomatoid carcinoma (1\%), one clear cell carcinoma, and one signet ring cell carcinoma. Tumor cells involved the surgical resection margin in 64 cases. Forty-one cases were stage IA disease (T1, N0, M0), 74 IB (T2, No, M0), 70 IIA (T3, No, M0), 78 IIB (T1, $\mathrm{T} 2$, or $\mathrm{T} 3, \mathrm{~N} 1, \mathrm{M} 0)$, and $26 \mathrm{III}$ (T4, any $\mathrm{N}, \mathrm{M0})$.

\section{Cytoplasmic KIT Expression in Extrahepatic Bile Duct Carcinomas}

Diffuse cytoplasmic KIT expression was observed in $54(19 \%)$ of 289 extrahepatic bile duct carcinomas (Figure 1). Comparisons between cytoplasmic KIT expression and clinicopathologic variables are summarized in Table 1. Among three pathologists who evaluated slides, the concurrence rate was 98\% (295 of 298 cases). In five cases that had discrepancy, we decided the proper layer based on the consensus opinion.

Cytoplasmic KIT was more frequently observed in cases with a papillary growth pattern (12 of 34 cases, $35 \%$ ) than in those with infiltrative (38 of 236 cases, $21 \%$ ) or nodular (four of 19 cases, $16 \%$ ) patterns (chi-square test, $P=0.03$ ). Cytoplasmic KIT was present in $25 \%$ of $\mathrm{T} 1$ tumors ( 12 of 48 cases), $12 \%$ of T2 tumors ( 13 of 105 cases), $25 \%$ of T3 tumors (27 of 110 cases), and $7 \%$ of T4 tumors (two of 26 cases, $P=0.04)$. There was no statistically significant correlation between cytoplasmic KIT expression and other clinicopathologic factors.

\section{Nuclear KIT Expression in Extrahepatic Bile Duct Carcinomas}

Nuclear KIT expression was observed in 58 (20\%) of 289 extrahepatic bile duct carcinomas (Figure 1). Comparisons between nuclear KIT expression and clinicopathologic variables are summarized in Table 1. Nuclear KIT expression was more frequently observed in cases with vascular invasion (27 of 79 cases, $34 \%$ ) than in those without vascular invasion (31 of 210 cases, $15 \%, P<0.001$ ). There was no statistically significant correlation between nuclear KIT expression and other clinicopathologic factors. Neither cytoplasmic nor nuclear KIT expression was observed in 20 normal biliary epithelia cases.

\section{Correlation between Cytoplasmic and Nuclear KIT in Extrahepatic Bile Duct Carcinomas}

Eleven of 289 extrahepatic bile duct carcinomas (4\%) showed both cytoplasmic and nuclear KIT expression (Figure 1), whereas 188 (65\%) were negative for both. Cytoplasmic KIT was observed in 

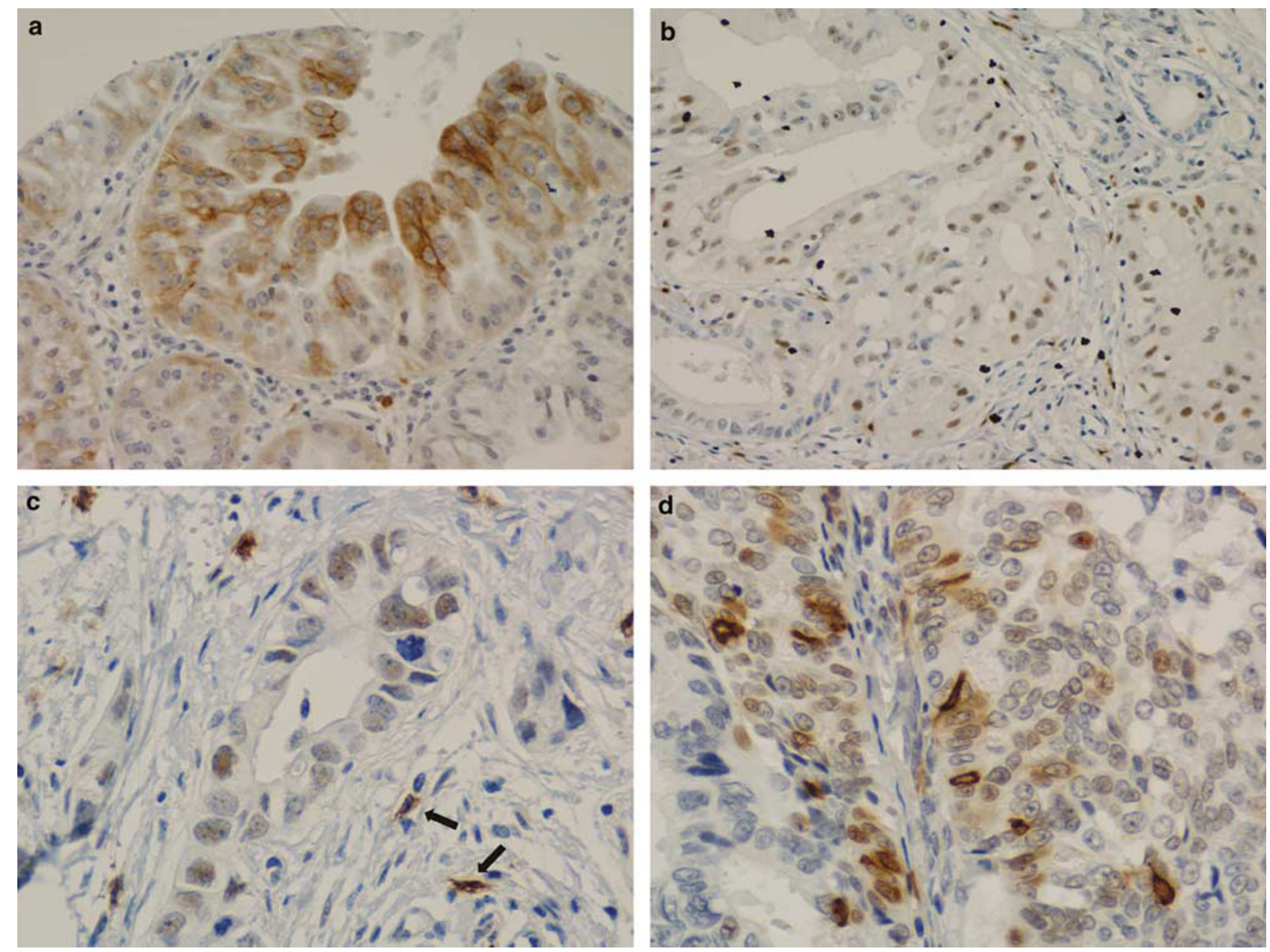

Figure 1 KIT expression in extrahepatic bile duct carcinoma. (a) A case of extrahepatic bile duct carcinoma shows cytoplasmic KIT expression $(\times 200)$. (b) A case of extrahepatic bile duct carcinoma shows nuclear KIT expression $(\times 200)$. (c) Mast cells in the stroma of extrahepatic bile duct carcinoma case are strongly stained (arrows) $(\times 400)$. (d) A case of extrahepatic bile duct carcinoma shows both cytoplasmic and nuclear KIT expression $(\times 200)$.

11 of 58 extrahepatic bile duct carcinomas with nuclear KIT expression (19\%), whereas it was observed in 43 of 231 without nuclear KIT (19\%). There was no significant correlation between cytoplasmic and nuclear KIT expression $(P=0.54)$.

\section{Mutational Analysis of $c$-kit Gene}

Mutational analysis of exon 11 was performed only in cases with cytoplasmic KIT expression, because imatinib mesylate (STI571, Gleevec) was effective for metastatic and/or unresectable GISTs, expressing cytoplasmic KIT. ${ }^{6,17,18}$ No mutation in exon 11 was identified among 20 extrahepatic bile duct carcinoma cases with cytoplasmic KIT expression.

\section{Patient Survival Based on KIT Expression}

The 5-year survival rate could be analyzed in 202 of 289 cases from 1991 to 2000. One-, three-, and fiveyear survival rates were, respectively, 83, 58, and
$50 \%$ for patients whose tumors were cytoplasmic KIT positive, as compared with 82,43 , and $28 \%$ of those whose extrahepatic bile duct carcinomas lacked cytoplasmic KIT. The median survival time of the cytoplasmic KIT expression group could not be obtained because 26 of 49 cases were censored. The median survival time for patients without KIT expression was 30 months. Patients in the cytoplasmic KIT-positive group show significantly better survival than those without cytoplasmic KIT expression (log-rank test, $P=0.01$, Table 2 and Figure 2).

Patients' survival time according to KIT expression was also compared after adjusting the $\mathrm{T}$ classification. When patients had cytoplasmic KIT expression, median survival time of $\mathrm{T} 1$ and $\mathrm{T} 2$ classification could not be measured because more than $50 \%$ of cases were censored (11 of 12 cases in T1; five of nine cases in T2). The median survival time of cases with cytoplasmic KIT expression was 13 months in T3 and 12 months in T4 classification. When patients did not show cytoplasmic KIT expression, median survival time was 45 months 
Table 1 Comparison between immunostaining results for KIT and clinicopathologic variables in extrahepatic bile duct carcinoma

\begin{tabular}{|c|c|c|c|c|}
\hline $\begin{array}{l}\text { Variable } \\
\text { (case number, } \\
\text { total } \mathrm{N}=289 \text { ) }\end{array}$ & $\begin{array}{c}\text { Cytoplasmic } \\
\text { KIT } \\
\text { expression }\end{array}$ & & $\begin{array}{l}\text { Nuclear } \\
\text { KIT } \\
\text { expression }\end{array}$ & P-value \\
\hline \multicolumn{5}{|l|}{ Sex } \\
\hline Male $(N=207)$ & 37 & 0.34 & 46 & 0.10 \\
\hline Female $(N=82)$ & 17 & & 12 & \\
\hline \multicolumn{5}{|l|}{ Growth pattern } \\
\hline Papillary $(N=34)$ & 12 & $0.03 *$ & 8 & 0.71 \\
\hline Nodular $(N=19)$ & 4 & & 3 & \\
\hline Infiltrative $(N=236)$ & 38 & & 47 & \\
\hline \multicolumn{5}{|l|}{ Differentiation } \\
\hline $\begin{array}{l}\text { Well differentiated } \\
(N=94)\end{array}$ & 16 & 0.81 & 15 & 0.23 \\
\hline $\begin{array}{l}\text { Moderately } \\
\text { differentiated } \\
(N=149)\end{array}$ & 30 & & 30 & \\
\hline $\begin{array}{l}\text { Poorly differentiated } \\
(N=46)\end{array}$ & 8 & & 13 & \\
\hline \multicolumn{5}{|l|}{ T classification } \\
\hline $\mathrm{T} 1(N=48)$ & 12 & $0.04 *$ & 9 & 0.66 \\
\hline $\mathrm{T} 2(N=105)$ & 13 & & 23 & \\
\hline Т3 $(N=110)$ & 27 & & 19 & \\
\hline $\mathrm{T} 4(N=26)$ & 2 & & 7 & \\
\hline \multicolumn{5}{|l|}{ Duodenal invasion } \\
\hline Absent $(N=263)$ & 52 & 0.10 & 51 & 0.25 \\
\hline Present $(N=26)$ & 2 & & 7 & \\
\hline \multicolumn{5}{|l|}{ Hepatic invasion } \\
\hline Absent $(N=277)$ & 51 & 0.39 & 57 & 0.09 \\
\hline Present $(N=12)$ & 3 & & 1 & \\
\hline \multicolumn{5}{|l|}{ Pancreatic invasion } \\
\hline Absent $(N=165)$ & 28 & 0.24 & 32 & 0.43 \\
\hline Present $(N=124)$ & 26 & & 26 & \\
\hline \multicolumn{5}{|l|}{ Perineural invasion } \\
\hline Absent $(N=94)$ & 21 & 0.17 & 20 & 0.42 \\
\hline Present $(N=195)$ & 33 & & 38 & \\
\hline \multicolumn{5}{|l|}{ Vascular invasion } \\
\hline Absent $(N=210)$ & 42 & 0.22 & 31 & $<0.001 *$ \\
\hline Present $(N=79)$ & 12 & & 27 & \\
\hline \multicolumn{5}{|l|}{ Lymph node metastasis } \\
\hline Absent $(N=197)$ & 37 & 0.54 & 39 & 0.49 \\
\hline Present $(N=92)$ & 17 & & 19 & \\
\hline \multicolumn{5}{|c|}{ Resection marginal status } \\
\hline Negative $(N=225)$ & 46 & 0.10 & 43 & 0.28 \\
\hline Positive $(N=64)$ & 8 & & 15 & \\
\hline \multicolumn{5}{|l|}{ Stage grouping } \\
\hline Stage IA $(N=41)$ & 10 & 0.06 & 8 & 0.92 \\
\hline Stage IB $(N=74)$ & 8 & & 15 & \\
\hline Stage IIA $(N=70)$ & 19 & & 13 & \\
\hline Stage IIB $(N=78)$ & 15 & & 15 & \\
\hline Stage III $(N=26)$ & 2 & & 7 & \\
\hline
\end{tabular}

${ }^{*}$ Significant at the significance level $<0.05$.

in T1, 23 months in T2, 28 months in T3, and 13 months in T4. There was also a significant survival difference based on cytoplasmic KIT expression after adjusting the T classification $(P=0.01)$.
Table 2 Univariate analysis of survival by clinicopathologic variables in patients with extrahepatic bile duct carcinoma

\begin{tabular}{|c|c|c|c|c|}
\hline Factor & Characteristics & Number & $\begin{array}{l}\text { Median } \\
\text { survival } \\
\text { (months) }\end{array}$ & $\mathrm{P}$-value \\
\hline \multirow[t]{2}{*}{ Sex } & Male & 145 & 34 & \multirow[t]{2}{*}{0.46} \\
\hline & Female & 57 & 27 & \\
\hline $\operatorname{Size}^{\mathrm{a}}$ & $2.5^{\mathrm{b}}$ & 202 & $33^{\mathrm{c}}$ & 0.18 \\
\hline \multirow[t]{3}{*}{ Growth pattern } & Papillary & 25 & 53 & \multirow[t]{3}{*}{0.001} \\
\hline & Nodular & 17 & - & \\
\hline & Infiltrative & 160 & 29 & \\
\hline \multirow[t]{4}{*}{ T classification } & $\mathrm{T} 1$ & 41 & - & \multirow[t]{4}{*}{$<0.001$} \\
\hline & $\mathrm{T} 2$ & 65 & 29 & \\
\hline & T3 & 86 & 27 & \\
\hline & $\mathrm{T} 4$ & 10 & 13 & \\
\hline \multirow{2}{*}{$\begin{array}{l}\text { Lymph node } \\
\text { metastasis }\end{array}$} & Present & 65 & 18 & \multirow[t]{2}{*}{$<0.001$} \\
\hline & Absent & 137 & 45 & \\
\hline Hepatic & Present & 11 & 18 & \multirow[t]{2}{*}{0.23} \\
\hline invasion & Absent & 191 & 33 & \\
\hline \multirow{2}{*}{$\begin{array}{l}\text { Pancreatic } \\
\text { invasion }\end{array}$} & Present & 84 & 27 & \multirow[t]{2}{*}{$0.03^{*}$} \\
\hline & Absent & 118 & 41 & \\
\hline \multirow{2}{*}{$\begin{array}{l}\text { Duodenal } \\
\text { invasion }\end{array}$} & Present & 10 & 13 & \multirow[t]{2}{*}{$0.003^{\prime}$} \\
\hline & Absent & 192 & 35 & \\
\hline \multirow{2}{*}{$\begin{array}{l}\text { Resection } \\
\text { marginal status }\end{array}$} & Positive & 44 & 20 & \multirow[t]{2}{*}{$0.04^{*}$} \\
\hline & Negative & 158 & 38 & \\
\hline \multirow{2}{*}{$\begin{array}{l}\text { Perineural } \\
\text { invasion }\end{array}$} & Present & 137 & 29 & \multirow[t]{2}{*}{0.07} \\
\hline & Absent & 65 & 50 & \\
\hline \multirow{4}{*}{$\begin{array}{l}\text { Vascular } \\
\text { invasion } \\
\text { KIT expression }\end{array}$} & Present & 48 & 19 & \multirow[t]{2}{*}{0.002} \\
\hline & Absent & 154 & 42 & \\
\hline & Present & 49 & Not & 0.01 * \\
\hline & Absent & 153 & $\begin{array}{c}\text { determined } \\
30\end{array}$ & \\
\hline
\end{tabular}

${ }^{\mathrm{a}}$ Continuous variable.

${ }^{\mathrm{b}}$ Mean.

${ }^{\mathrm{C}}$ Median survival time at mean.

${ }^{*}$ Significant at the significance level $<0.05$.

One-, three-, and five-year survival rates were, respectively, 85,37 , and $36 \%$ for patients whose tumors expressed KIT in the nuclei (median survival time, 25 months), whereas survival rates were 83, 48 , and $34 \%$ for those whose extrahepatic bile duct carcinomas lacked nuclear KIT expression (median, 35 months). No survival difference was identified based on the nuclear expression of KIT $(P=0.59)$.

\section{Univariate Analysis of Survival by Clinicopathologic Factors}

The median survival times of patients with papillary and infiltrative extrahepatic bile duct carcinomas were 53 and 28 months, respectively. The median survival time of patients with a nodular pattern was not obtained because more than half of patients (nine of 17 cases) were alive after five-year followup. The median survival time of patients with T1 tumors was also not obtained. The median survival times of patients with T2, T3, and T4 tumors were 29, 27, and 13 months, respectively. The median survival times in association with other clinicopathologic factors are summarized in Table 2. 


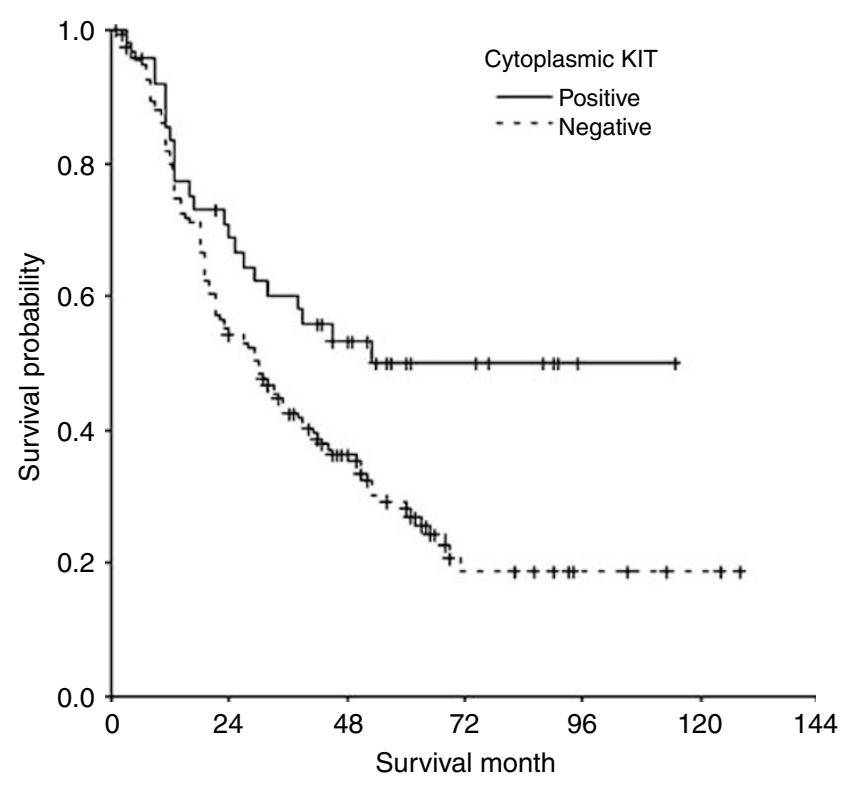

Figure 2 Kaplan-Meier survival analysis based on the cytoplasmic KIT expression of extrahepatic bile duct carcinoma. The median survival of cytoplasmic KIT expression group is not obtained because 23 of 49 patients are censored. The median survival time of the cytoplasmic KIT negative group is 30 months. Patients in the cytoplasmic KIT positive group show significantly better survival than those without cytoplasmic KIT expression (log-rank test, $P=0.01$ ).

Other factors that were associated with the patients' survival times were tumor growth pattern $(P=0.001)$, T classification $(P<0.001)$, lymph node metastasis $(P<0.001)$, and pancreas $(P=0.03)$, duodenal $(P=0.003)$, and vascular $(P=0.002)$ invasions, and resection marginal involvement $(P=0.04)$. Patients' sex, tumor size, hepatic invasion, and perineural invasion were not statistically significant factors.

\section{Multivariate Analysis of Prognosis}

The prognostic significance based on cytoplasmic KIT expression, along with other prognostically significant clinicopathologic variables, was further analyzed by the Cox proportional hazards model. Multivariate analysis revealed that cytoplasmic KIT expression $(P=0.04)$ was an independent prognostic factor along with T classification $(P=0.02)$ and lymph node metastasis $(P=0.002$, Table 3$)$.

\section{Discussion}

Although a previous study reported that cytoplasmic KIT expression was observed in $30 \%$ of cholangiocarcinomas, ${ }^{19}$ this figure is not fully accurate because of the limited number of cases tested. In this study, cytoplasmic KIT expression was observed in $19 \%$ of 289 cases of extrahepatic bile duct carcinoma. The infrequent cytoplasmic KIT expression along with the lack of mutations in
Table 3 Multivariate analysis of prognosis by clinicopathologic variables in patients with extrahepatic bile duct carcinoma

\begin{tabular}{lccc}
\hline Variables & P-value & $\begin{array}{c}\text { Relative } \\
\text { risk }\end{array}$ & $\begin{array}{c}95 \% \text { confidence } \\
\text { interval }\end{array}$ \\
\hline $\begin{array}{l}\text { Cytoplasmic KIT } \\
\text { expression }\end{array}$ & $0.04^{*}$ & 1.599 & $1.011-2.529$ \\
$\begin{array}{l}\text { Growth pattern } \\
\text { T classification }\end{array}$ & 0.33 & 1.601 & $0.885-3.334$ \\
Lymph node metastasis & $0.02^{*}$ & 1.632 & $1.241-1.389$ \\
Pancreatic invasion & 0.39 & 1.848 & $1.256-3.245$ \\
$\begin{array}{l}\text { Duodenal invasion } \\
\text { Resection marginal status }\end{array}$ & 0.26 & 1.415 & $0.637-3.144$ \\
Vascular invasion & 0.07 & 1.492 & $0.728-3.257$ \\
& 0.06 & 1.490 & $0.965-2.298$ \\
\hline
\end{tabular}

* Significant at the significance level $<0.05$.

exon 11 of $c$-kit suggests that imatinib mesylate cannot be used as a good therapeutic regimen in extrahepatic bile duct carcinoma, and this also suggests that $c$-kit mutations in different exons, such as exons 9, 13, or 17, may contribute to KIT expression in extrahepatic bile duct carcinoma.

In this study, we did not perform immunohistochemistry for KIT on conventionally sectioned slides. Because of a concern about tissue core representativity, comparing tissue microarray with whole-section histology was considered by many pathologists when tissue microarray technology was developed. However, previous studies demonstrated that 2-4 tissue cores are representative with a 95-97\% concordance rate. ${ }^{23}$

Cytoplasmic KIT expression has been reported in many neoplasms from different organs with a variable prognostic significance. It was reported to indicate poor prognosis in small-cell and large-cell neuroendocrine lung carcinomas and endometrial carcinomas. $^{24-28}$ In contrast, cytoplasmic KIT expression indicated an increased survival rate in patients with neuroblastoma, hepatocellular carcinoma, and breast cancer. ${ }^{29-31}$

Several reports described the nuclear translocation of membrane tyrosine kinase receptors, including epidermal growth factor receptor (EGFR), ${ }^{32}$ fibroblast growth factor receptor (FGFR), ${ }^{33}$ nerve growth factor receptor (NGFR), ${ }^{34}$ PDGFR, ${ }^{35}$ ErbB2(HER-2/neu) ${ }^{36}$ ErbB-3 $3{ }^{37}$ and ErbB- $4 .{ }^{38}$ Nuclear KIT expression was described in several normal tissues and benign and malignant tumors, including normal medullary cells of adrenal glands, pheochromocytomas, ${ }^{39}$ sarcomatoid renal cell carcinomas, ${ }^{40}$ and GISTs. ${ }^{41}$ Although the previous reports described KIT expression in the nuclei in a limited number of cases, the clinical significance of nuclear KIT expression remained unclear. In the present study, we observed nuclear KIT expression in $20 \%$ of extrahepatic bile duct carcinomas. In contrast to the well-elucidated function of other membrane receptor tyrosine kinases,$^{42}$ the implication of nuclear KIT expression is not fully understood. However, several pieces of evidence, such as the transactivation 
function of another tyrosine kinase receptor Erb-1 and its binding to a specific DNA sequence, ${ }^{43}$ suggest that nuclear localization of KIT may also have a transcriptional function.

Regarding the clinical aspect, the significance of nuclear translocation of the KIT tyrosine kinase receptor is unclear. Breast cancer patients with nuclear expression of EGFR demonstrated poorer survival rates than those without nuclear expression. ${ }^{44}$ One study of oropharyngeal squamous cell carcinoma reported nuclear EGFR expression to be correlated with local recurrence; however, they did not find any significant correlation between EGFR nuclear expression and patient survival rate. ${ }^{45} \mathrm{We}$ observed more frequent vascular invasion in extrahepatic bile duct carcinoma when nuclear KIT expression was present, suggesting that nuclear KIT expression may be associated with tumor progression in extrahepatic bile duct carcinoma. However, we did not observe any significant effect on patient survival between cases with and without nuclear KIT expression.

Although our study demonstrated the presence of nuclear KIT expression and its association with tumor progression, many questions about the role of nuclear KIT expression remain. Dysregulation of the SCF-KIT signaling pathway has been observed in many other malignant neoplasms. ${ }^{46}$ Furthermore, the expression of KIT in cases, which do not harbor KIT mutations, is not correlated with responsiveness to imatinib mesylate. ${ }^{46}$ Thus, further studies of nuclear KIT expression may reveal the mechanism of unresponsiveness to imatinib mesylate in these patients and may facilitate the development of the other alternative therapeutic regimens for patients who are nonresponsive to imatinib mesylate.

In summary, cytoplasmic KIT expression was observed in $19 \%$ of cases with extrahepatic bile duct carcinoma. Owing to the infrequency of cytoplasmic KIT expression and the lack of exon 11 mutations, imatinib mesylate may not be a good therapeutic regimen in the treatment of patients with extrahepatic bile duct carcinoma. However, cytoplasmic KIT expression may be used as a prognostic indicator. Nuclear KIT expression was identified in $20 \%$ of cases with extrahepatic bile duct carcinoma and was positively correlated with tumor progression. Like other tyrosine kinase receptors, nuclear KIT may play a different role from that of its membrane counterpart. Therefore, further functional studies of nuclear KIT expression are needed.

\section{Acknowledgements}

This study was supported by a grant (2005-039) from the Asan Institute of Life Sciences, Seoul, Korea. We thank Mr Jae Nam Kho and Ms Seol Paik for their technical assistance and Ms Kimberly Walter for editing the manuscript.

\section{References}

1 Hong SM, Kim MJ, Pi DY, et al. Analysis of extrahepatic bile duct carcinomas according to the New American Joint Committee on Cancer staging system focused on tumor classification problems in 222 patients. Cancer 2005;104:802-810.

2 Yarden Y, Kuang WJ, Yang-Feng T, et al. Human protooncogene c-kit: a new cell surface receptor tyrosine kinase for an unidentified ligand. EMBO J 1987;6: 3341-3351.

3 Funasaka Y, Boulton T, Cobb M, et al. c-Kit-kinase induces a cascade of protein tyrosine phosphorylation in normal human melanocytes in response to mast cell growth factor and stimulates mitogen-activated protein kinase but is down-regulated in melanomas. Mol Biol Cell 1992;3:197-209.

4 Ratajczak MZ, Luger SM, DeRiel K, et al. Role of the KIT protooncogene in normal and malignant human hematopoiesis. Proc Natl Acad Sci USA 1992;89: 1710-1714.

5 Broxmeyer HE, Maze R, Miyazawa K, et al. The kit receptor and its ligand, steel factor, as regulators of hemopoiesis. Cancer Cells 1991;3:480-487.

6 Hirota S, Isozaki K, Moriyama Y, et al. Gain-of-function mutations of c-kit in human gastrointestinal stromal tumors. Science 1998;279:577-580.

7 Inoue M, Kyo S, Fujita M, et al. Coexpression of the c-kit receptor and the stem cell factor in gynecological tumors. Cancer Res 1994;54:3049-3053.

8 Rajpert-De Meyts E, Skakkebaek NE. Expression of the c-kit protein product in carcinoma-in-situ and invasive testicular germ cell tumours. Int J Androl 1994;17: 85-92.

9 Halaban R, Fan B, Ahn J, et al. Growth factors, receptor kinases, and protein tyrosine phosphatases in normal and malignant melanocytes. J Immunother 1992;12: 154-161.

10 Cohen PS, Chan JP, Lipkunskaya M, et al. Expression of stem cell factor and c-kit in human neuroblastoma. The Children's Cancer Group. Blood 1994;84: 3465-3472.

11 Hines SJ, Organ C, Kornstein MJ, et al. Coexpression of the c-kit and stem cell factor genes in breast carcinomas. Cell Growth Differ 1995;6:769-779.

12 Pietsch T, Nicotra MR, Fraioli R, et al. Expression of the c-Kit receptor and its ligand SCF in non-small-cell lung carcinomas. Int J Cancer 1998;75:171-175.

13 Elmore LW, Domson K, Moore JR, et al. Expression of c-kit (CD117) in benign and malignant human endometrial epithelium. Arch Pathol Lab Med 2001;125: 146-151.

14 Heinrich MC, Blanke CD, Druker BJ, et al. Inhibition of KIT tyrosine kinase activity: a novel molecular approach to the treatment of KIT-positive malignancies. J Clin Oncol 2002;20:1692-1703.

15 Joensuu H, Dimitrijevic S. Tyrosine kinase inhibitor imatinib (STI571) as an anticancer agent for solid tumours. Ann Med 2001;33:451-455.

16 Dagher R, Cohen M, Williams G, et al. Approval summary: imatinib mesylate in the treatment of metastatic and/or unresectable malignant gastrointestinal stromal tumors. Clin Cancer Res 2002;8: 3034-3038.

17 Kindblom LG, Remotti HE, Aldenborg F, et al. Gastrointestinal pacemaker cell tumor (GIPACT): gastrointestinal stromal tumors show phenotypic char- 
acteristics of the interstitial cells of Cajal. Am J Pathol 1998;152:1259-1269.

18 Sarlomo-Rikala M, Kovatich AJ, Barusevicius A, et al. CD117: a sensitive marker for gastrointestinal stromal tumors that is more specific than CD34. Mod Pathol 1998;11:728-734.

19 Holcombe RF, Gu M, Imagawa D, et al. Expression of Kit and platelet-derived growth factor receptors alpha and beta in cholangiocarcinoma, and case report of therapy with imatinib mesylate (STI571). Anticancer Drugs 2003;14:651-657.

20 Hong SM, Kang GH, Lee HY, et al. Smooth muscle distribution in the extrahepatic bile duct: histologic and immunohistochemical studies of 122 cases. Am J Surg Pathol 2000;24:660-667.

21 Hong SM, Cho H, Moskaluk CA, et al. CDX2 and MUC2 protein expression in extrahepatic bile duct carcinoma. Am J Clin Pathol 2005;124:361-370.

22 Hong SM, Choi J, Ryu K, et al. Promoter hypermethylation of the p16 gene and loss of its protein expression is correlated with tumor progression in extrahepatic bile duct carcinomas. Arch Pathol Lab Med 2006;130: 33-38.

23 Watanabe A, Cornelison R, Hostetter G. Tissue microarrays: applications in genomic research. Expert Rev Mol Diagn 2005;5:171-181.

24 Rohr UP, Rehfeld N, Pflugfelder L, et al. Expression of the tyrosine kinase c-kit is an independent prognostic factor in patients with small cell lung cancer. Int J Cancer 2004;111:259-263.

25 Casali C, Stefani A, Rossi G, et al. The prognostic role of c-kit protein expression in resected large cell neuroendocrine carcinoma of the lung. Ann Thorac Surg 2004;77:247-252; discussion 52-53.

26 Scobie JV, Acs G, Bandera CA, et al. C-kit immunoreactivity in endometrial adenocarcinomas and its clinicopathologic significance. Int J Gynecol Pathol 2003;22:149-155.

27 Micke P, Basrai M, Faldum A, et al. Characterization of c-kit expression in small cell lung cancer: prognostic and therapeutic implications. Clin Cancer Res 2003; 9:188-194

28 Naeem M, Dahiya M, Clark JI, et al. Analysis of c-kit protein expression in small-cell lung carcinoma and its implication for prognosis. Hum Pathol 2002;33: 1182-1187.

29 Chung CY, Yeh KT, Hsu NC, et al. Expression of c-kit protooncogene in human hepatocellular carcinoma. Cancer Lett 2005;217:231-236.

30 Tsutsui S, Yasuda K, Suzuki K, et al. A loss of c-kit expression is associated with an advanced stage and poor prognosis in breast cancer. Br J Cancer 2006;94: 1874-1878.

31 Krams M, Parwaresch R, Sipos B, et al. Expression of the c-kit receptor characterizes a subset of neuroblas- tomas with favorable prognosis. Oncogene 2004;23: 588-595.

32 Marti U, Burwen SJ, Wells A, et al. Localization of epidermal growth factor receptor in hepatocyte nuclei. Hepatology 1991;13:15-20.

33 Maher PA. Nuclear Translocation of fibroblast growth factor (FGF) receptors in response to FGF-2. J Cell Biol 1996;134:529-536.

34 Rakowicz-Szulczynska EM, Herlyn M, Koprowski H. Nerve growth factor receptors in chromatin of melanoma cells, proliferating melanocytes, and colorectal carcinoma cells in vitro. Cancer Res 1988;48:7200-7206.

35 Rakowicz-Szulczynska EM, Rodeck U, Herlyn M, et al. Chromatin binding of epidermal growth factor, nerve growth factor, and platelet-derived growth factor in cells bearing the appropriate surface receptors. Proc Natl Acad Sci USA 1986;83:3728-3732.

36 Wang SC, Lien HC, Xia W, et al. Binding at and transactivation of the COX-2 promoter by nuclear tyrosine kinase receptor ErbB-2. Cancer Cell 2004;6: 251-261.

37 Offterdinger M, Schofer C, Weipoltshammer K, et al. c-erbB-3: a nuclear protein in mammary epithelial cells. J Cell Biol 2002;157:929-939.

38 Ni CY, Murphy MP, Golde TE, et al. Gamma-secretase cleavage and nuclear localization of ErbB-4 receptor tyrosine kinase. Science 2001;294:2179-2181.

39 Matsuda R, Takahashi T, Nakamura S, et al. Expression of the c-kit protein in human solid tumors and in corresponding fetal and adult normal tissues. Am J Pathol 1993;142:339-346.

40 Castillo M, Petit A, Mellado B, et al. C-kit expression in sarcomatoid renal cell carcinoma: potential therapy with imatinib. J Urol 2004;171:2176-2180.

41 Di Matteo G, Pescarmona E, Peparini $\mathrm{N}$, et al. Histopathological features and clinical course of the gastrointestinal stromal tumors. Hepato-gastroenterology 2002;49:1013-1016.

42 Wang SC, Hung MC. Cytoplasmic/nuclear shuttling and tumor progression. Ann NY Acad Sci 2005;1059: 11-15.

43 Lin SY, Makino K, Xia W, et al. Nuclear localization of EGF receptor and its potential new role as a transcription factor. Nat Cell Biol 2001;3:802-808.

44 Lo HW, Xia W, Wei Y, et al. Novel prognostic value of nuclear epidermal growth factor receptor in breast cancer. Cancer Res 2005;65:338-348.

45 Psyrri A, Yu Z, Weinberger PM, et al. Quantitative determination of nuclear and cytoplasmic epidermal growth factor receptor expression in oropharyngeal squamous cell cancer by using automated quantitative analysis. Clin Cancer Res 2005;11:5856-5862.

46 Tornillo L, Terracciano LM. An update on molecular genetics of gastrointestinal stromal tumours. J Clin Pathol 2006;59:557-563. 